Rev Biomed 2004; 15:33-48.

\title{
Transactivación de receptores con actividad de cinasa de tirosina (RTK's) por receptores acoplados a proteínas $G$.
}

Revisión

Enrique Sánchez-Lemus, José A. Arias-Montaño.

Departamento de Fisiología, Biofísica y Neurociencias, Centro de Investigación y de Estudios Avanzados (Cinvestav), México, D.F., México.

\section{RESUMEN.}

Los efectos de los factores de crecimiento y de ciertas hormonas se deben a la activación de receptores con actividad intrínseca de cinasa de tirosina (o RTK's, por receptor tyrosine kinases), cuya estimulación inicia cascadas de señalización intracelular que regulan eventos transcripcionales esenciales para la proliferación y la diferenciación celulares. Entre los efectos debidos a la estimulación de los RTK's, destaca la activación de la familia de cinasas de proteína activadas por mitógeno o

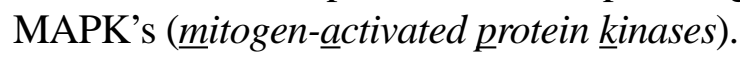

Existen evidencias que indican que la estimulación de algunos receptores acoplados a proteínas $\mathrm{G}$ (o GPCR's, por $\underline{G}$ protein- $\underline{\text { coupled }}$ receptors) resulta en la activación de RTK's en ausencia de un ligando para estos últimos. Este proceso ha sido denominado transactivación, y depende de señales intracelulares inducidas por la estimulación de GPCR's en las que participan tanto las subunidades a como los complejos bog de las proteínas G, así como fenómenos de fosforilación mediados por diferentes cinasas. En este artículo se revisan las características estructurales de ambos tipos de receptores (GPCR's y RTK's), los mecanismos responsables de su activación y los procesos involucrados en el fenómeno de transactivación de RTK's por activación de GPCR's. (Rev Biomed 2004; 15:33-48)

Palabras clave: Cinasa de tirosina, receptores de cinasa de tirosina, proteinas $\mathrm{G}$, receptores acoplados a proteina $\mathrm{C}$.

\section{SUMMARY.}

Transactivation of tyrosine kinase receptors (RTK's) by G protein-coupled receptors (GPCR's).

The effects of growth factors and those of some hormones are mediated by the activation of receptors with an intrinsic activity of tyrosine kinase (receptor tyrosine kinases, RTK's); whose stimulation triggers signalling cascades that regulate transcriptional events crucial for cell growth and differentiation. Among the effects that follow RTK stimulation, the activation of the family of mitogen-activated protein kinases (MAPK's) bears particular relevance.

Solicitud de sobretiros: Dr. José A. Arias-Montaño, Departamento de Fisiología, Biofísica y Neurociencias, Cinvestav, Apartado Postal 14740, C.P. 07000, México, D.F., México.

Tel. (55) $57473964 \quad$ Fax: (55) $57473754 \quad$ E-mail: jaarias@fisio.cinvestav.mx

Recibido el 29/Abril/2003. Aceptado para publicación el 30/Octubre/2003.

Este artículo está disponible en http://www.uady.mx/sitios/biomedic/revbiomed/pdf/rb041516.pdf

Vol. 15/No. 1/Enero-Marzo, 2004 


\section{E Sánchez-Lemus, JA Arias-Montaño.}

There is evidence that the stimulation of several G protein-coupled receptors (GPCR's) results in RTK activation in the absence of ligands for the latter. This phenomenon is known as transactivation, and relies on intracellular signals induced by GPCR stimulation, in which both the a subunit and the bog complexes of the corresponding $\mathrm{G}$ proteins, as well as phosphorylation processes mediated by different kinases are involved. Herein we review the mechanisms responsible for the activation of GPCR's and RTK's, as well as the characteristics of RTK transactivation by GPCR's.

\section{(Rev Biomed 2004; 15:33-48)}

Key words: Tyrosine kinase, receptor tyrosine kinase, $\mathrm{G}$ protein, $\mathrm{G}$ protein-coupled receptors.

\begin{tabular}{|c|c|}
\hline \multicolumn{2}{|c|}{ Abreviaturas } \\
\hline a $a$ & Aminoácidos \\
\hline$A C$ & adenilil ciclasa \\
\hline$A M P c$ & monofosfato cíclico de adenosina \\
\hline$C R E$ & elemento de respuesta al AMPc \\
\hline$C R E B$ & proteína de unión a CRE \\
\hline$D A G$ & Diacilglicerol \\
\hline$E G F$ & factor de crecimiento epidérmico \\
\hline$E G F-R$ & receptor para EGF \\
\hline$E R K^{\prime} s$ & $\begin{array}{l}\text { cinasas reguladas por señales extracelulares } \\
\text { (extracellular signal-regulated kinases) }\end{array}$ \\
\hline GAP's & $\begin{array}{l}\text { proteínas estimuladoras de la actividad de GTPasa } \\
\text { (GTPase activating proteins) }\end{array}$ \\
\hline GNRP's & $\begin{array}{l}\text { proteínas liberadoras de nucleótidos de guanina } \\
\text { (guanine-nucleotide releasing proteins) }\end{array}$ \\
\hline$G P C R$ 's & $\begin{array}{l}\text { receptores acoplados a proteínas } \mathrm{G} \\
\text { ( } G \text { protein-coupled receptors) }\end{array}$ \\
\hline$G P C R ' s-G q$ & receptores acoplados a proteínas Gq \\
\hline$G P C R$ 's-Gs & receptores acoplados a proteínas Gs \\
\hline GPCR's-Gi/o & receptores acoplados a proteínas Gi/o \\
\hline$H B-E G F$ & EGF unido a heparina \\
\hline $\operatorname{Ins}(1,4,5) P 3$ & 1,4,5-trifosfato de inositol \\
\hline$J A K ' s$ & cinasas Janus \\
\hline$M A P K ' s$ & $\begin{array}{l}\text { cinasas de proteína activadas por mitógenos } \\
\text { (mitogen-activated protein kinases) }\end{array}$ \\
\hline$M E K$ & cinasa de ERK/MAPK \\
\hline$P I 3-K$ & 3-cinasa del fosfatidil inositol \\
\hline$P K A$ & cinasa A de proteína \\
\hline$P K C$ & cinasa $\mathrm{C}$ de proteína \\
\hline$c P K C$ & PKC's convencionales \\
\hline$n P K C$ & PKC's nuevas \\
\hline$P L C$ & fosfolipasa $\mathrm{C}$ \\
\hline$R T K$ 's & $\begin{array}{l}\text { receptores con actividad de cinasa de tirosina } \\
\text { (receptor tyrosine kinases) }\end{array}$ \\
\hline $\mathrm{SH} 2$ & región 2 de homología a Src \\
\hline SNC & sistema nervioso central \\
\hline STAT's & $\begin{array}{l}\text { ansductores y activadores de la señal de transcripción } \\
\text { (signal transducers and activators of transcription) }\end{array}$ \\
\hline
\end{tabular}

\section{INTRODUCCIÓN.}

La unión de los neurotransmisores, hormonas o factores de crecimiento (ligandos) a sus receptores membranales, produce cambios bioquímicos en el interior de la célula, que conducen a una respuesta específica para el estímulo recibido. Existen tres grandes grupos de receptores membranales, definidos por sus mecanismos de transducción de señales: a) receptores que son canales iónicos o ionotrópicos; b) receptores acoplados a proteínas G o GPCR's (por $\underline{G}$ protein-coupled receptors) y c) receptores con actividad de cinasa de tirosina o RTK's (por receptor tyrosine kinases).

Los RTK's son activados de manera primaria por factores de crecimiento y su estimulación inicia cascadas de señalización que regulan eventos transcripcionales esenciales para la proliferación y la diferenciación celulares, en las que participa de manera relevante la familia de cinasas de proteína activadas por mitógenos (mitogen-activated protein kinases, MAPK's). Por otra parte, los GPCR's se encuentran involucrados en la activación de un gran número de cascadas de señalización, que en última instancia modifican la función de canales iónicos, receptores y enzimas, así como la transcripción de genes.

Desde mediados de la década de los 90 se han generado evidencias que muestran que la estimulación de GPCR's resulta en la activación de RTK's en ausencia de un ligando de estos últimos. Este proceso ha sido denominado transactivación, y depende de señales intracelulares, en las que participan tanto las subunidades a como los complejos tog de las proteínas G, como fenómenos de fosforilación debidos a la cinasa C de proteína (PKC) y a cinasas de tirosina, diferentes de los propios RTK's (1-3). En este artículo se revisan los mecanismos de activación de ambas familias de receptores (acoplados a proteínas $\mathrm{G}$ y con actividad intrínseca de cinasa de tirosina), así como las evidencias más relevantes del fenómeno de transactivación de RTK's por estimulación de GPCR's. 
Receptores de cinasa de tirosina y receptores acoplados a proteínas $G$.

SEÑALIZACIÓN INTRACELULAR MEDIADA POR RECEPTORES ACOPLADOS A PROTEÍNAS G (GPCR's).

\section{RECEPTORES.}

Son proteínas que conforman la familia más grande ( 1000 diferentes miembros) de receptores membranales involucrados en la transmisión de señales, activados por una amplia variedad de ligandos, como neurotransmisores, hormonas, factores de crecimiento, moléculas odorantes y la luz. Sus funciones biológicas son múltiples y de suma relevancia e incluyen la neurotransmisión, la regulación de la secreción endocrina y exócrina, la quimiotaxis, el control de la presión arterial, la embriogénesis, la percepción de la luz, el crecimiento y desarrollo celulares y la oncogénesis (4). Si bien estos receptores presentan particularidades estructurales que les permiten reconocer a su ligando específico, comparten características similares que se mencionan a continuación.

$\mathrm{Su}$ estructura consiste de una sola cadena protéica de 550 a 1200 aminoácidos (aa), que cruza siete veces la membrana celular (segmentos de 20-27 aa cada uno) con el extremo amino terminal (7-595 aa) en la región extracelular y el carboxilo terminal (12359 aa) en la intracelular. Los cruces repetidos en la membrana plasmática dan lugar a seis asas de 5-230 aa (figura 1A), 3 intracelulares $\left(i_{1}-i_{3}\right)$ y 3 extracelulares $\left(\mathrm{e}_{1}-\mathrm{e}_{3}\right)$. Tres de los segmentos transmembranales $(1,4$ y 7) son altamente hidrofóbicos, mientras que los segmentos 2, 3, 5 y 6 contienen residuos hidrofóbicos, iónicos y neutros. En consecuencia, los segmentos 1, 4 y 7 permanecen en la parte externa del receptor y en contacto estrecho con la membrana, y los segmentos 2, 3, 5 y 6 se mantienen en el centro de la estructura, donde forman un núcleo transmembranal que en la mayoría de los receptores participa en la unión del ligando (5) (ver figura 1B).

La localización de las regiones amino y carboxilo terminales permiten también regular la funcionalidad del receptor, ya que la región amino puede ser glicosilada y la región carboxilo está expuesta a otras moléculas de señalización, como cinasas y las proteínas arrestinas, responsables de procesos de sensibilización, desensibilización e internalización (6). Además, la región carboxilo terminal y las asas intracelulares $\mathrm{i}_{2} \mathrm{e}_{3}$ son críticas para la transducción de la señal hacia el interior de la célula, ya que son los dominios de unión a la proteína $\mathrm{G}$ correspondiente, responsable de iniciar la señalización intracelular.

\section{PROTEÍNAS G.}

Son heterotrímeros presentes en todos los organismos eucariotes. Tienen un papel esencial en la transducción de señales ya que asocian al receptor con las proteínas efectoras localizadas en el interior celular. Las subunidades que las conforman son a (39-46 $\mathrm{KDa})$, b (37 KDa) y g( $8 \mathrm{KDa})$, con las subunidades by gfuncionando como una sola unidad al formar un complejo estrechamente asociado.

La subunidad a de las proteínas $G$ posee un sitio de unión con alta afinidad por nucleótidos de guanina

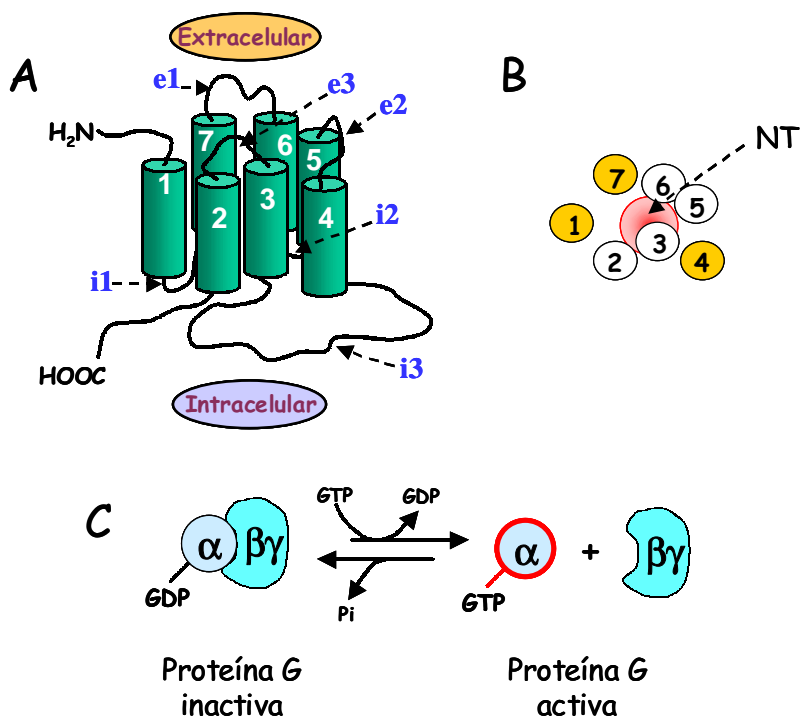

Figura 1.- Estructura de los receptores acoplados a proteínas $G$ (GPCR's) y activación de proteínas G. A) Estructura típica de un GPCR con siete dominios transmembranales (1-7), tres asas intracelulares (i1-i3) y tres extracelulares (e1-e3), con el extremo amino terminal en la región extracelular y el carboxilo terminal en la región intracelular. Las asas i2 e i3 y el extremo carboxilo terminal participan en el acople a la proteína G. B) Vista extracelular del receptor donde se esquematiza el núcleo transmembranal (NT), sitio de unión del ligando en la mayoría de los receptores. C) Al ser activada por el receptor, la subunidad a de la proteína $G$ intercambia el GDP por GPT y se disocia del complejo bog. Tanto la subunidad a-GTP como el complejo bog actúan sobre diversos sistemas efectores. Posteriormente, la actividad intrínseca de GTPasa de la subunidad a hidroliza el GTP generando GDP y pirofosfato $(\mathrm{Pi})$, lo que inactiva a la subunidad a e induce el reacoplamiento del trímero abg.

Vol. 15/No. 1/Enero-Marzo, 2004 
E Sánchez-Lemus, JA Arias-Montaño.

(GTP o GDP), así como actividad de GTPasa que hidroliza el GTP a GDP (7). Debido a esta característica, las proteínas $\mathrm{G}$ pueden encontrarse en dos estados: con la subunidad a asociada a GDP y unida al complejo bog (estado inactivo), y con la subunidad asociada a GTP y disociada del complejo bog (estado activo; figura 1C). En el estado activo, tanto la subunidad como el complejo actúan sobre proteínas efectoras. Por ejemplo, las proteínas Gq estimulan a la fosfolipasa C (PLC) induciendo la formación de dos segundos mensajeros, el 1,4,5-trifosfato de inositol $\left[\operatorname{Ins}(1,4,5) \mathrm{P}_{3}\right.$ ó $\left.\mathrm{IP}_{3}\right]$ y el diacilglicerol (DAG), mientras que las proteínas Gas y Gai estimulan e inhiben, respectivamente, la formación del monofosfato cíclico de adenosina (AMPc) por acción sobre la enzima adenilil ciclasa (AC) (ver cuadro 1 para más información). Los efectos sobre la PLC y la AC se deben básicamente a la acción de la subunidad $a$, por lo que inicialmente el complejo bog fue considerado sólo como una entidad de anclaje de la proteína $\mathrm{G}$; sin embargo, en la actualidad es evidente que las subunidades bog actúan directamente sobre otras proteínas, como canales iónicos o enzimas (cuadro 1) (8).

\section{SEÑALIZACIÓN.}

La señalización mediada por GPCR's se inicia al formarse el complejo ligando-receptor-proteína $\mathrm{G}$, conocido también como "complejo ternario". Un modelo sencillo que representa la activación de un GPCR es el modelo extendido del complejo ternario que propone que el receptor existe en dos estados, uno inactivo (R), no acoplado a proteínas $\mathrm{G}$, y un estado $\left(R^{*}\right)$ que puede acoplarse a la proteína $G$ correspondiente $\left(R^{*} \mathrm{G}\right)$ y que es el que eventualmente, al unirse el ligando $(\mathrm{L})$, induce una respuesta funcional:

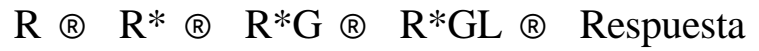

\section{Cuadro 1}

Familias de las subunidades $a, b$ y gque conforman a las proteínas $\mathbf{G}$.

\begin{tabular}{|c|c|c|}
\hline Familia & Subtipos y distribución & Funciones \\
\hline $\mathrm{a} \mathbf{s}$ & $\begin{array}{l}\text { as: ubicua } \\
\text { aolf: cerebro / neuroepitelio olfatorio }\end{array}$ & $\begin{array}{l}\mathrm{AC}(+) ; \operatorname{VDCC}(+) ; \text { canales de } \mathrm{Na}^{+}(+) ; \\
\text {canales de } \mathrm{Cl}^{-}(+)\end{array}$ \\
\hline $\mathrm{a} \mathbf{i} / \mathbf{o}$ & $\begin{array}{l}\text { ai1, ai2, ai3: amplia } \\
\text { aoA, aoB: cerebro }\end{array}$ & $\begin{array}{l}\mathrm{AC}(-) \text {; canales de } \mathrm{K}^{+}(+) \text {; } \operatorname{VDCC}(-) \\
\text { canales de } \mathrm{Na}^{+}(-) \text {; canales de } \mathrm{Cl}^{-}(-)\end{array}$ \\
\hline $\begin{array}{l}\mathrm{at} \\
\mathrm{aq}, \mathrm{a} \mathbf{1 1}\end{array}$ & $\begin{array}{l}\text { at1, at2: retina } \\
\text { aq, a11: amplia } \\
\text { a14: pulmón / riñón / hígado } \\
\text { a15: células B / células mieloides } \\
\text { a16: células T / células mieloides }\end{array}$ & $\begin{array}{l}\operatorname{PDE}(+) \\
\text { PLC-b }(+)\end{array}$ \\
\hline $\mathrm{a} 12 / 13$ & $\begin{array}{l}\text { a12: amplia } \\
\text { a13: amplia }\end{array}$ & PGP (+); KTnR (+) \\
\hline bg & $\begin{array}{l}\mathrm{b}_{1}-\mathrm{b}_{2}: \text { amplia } \\
\mathrm{g}_{1}-\mathrm{g}_{7}: \text { amplia }\end{array}$ & $\begin{array}{l}\text { ACII y IV (+); ACI (-); PLC-b (+); } \\
\text { VDCC (-); PI3-K (+); PGP (+); KTnR (+) }\end{array}$ \\
\hline
\end{tabular}

AC, adenilil ciclasa; VDCC, canales de $\mathrm{Ca}^{2+}$ dependientes de voltaje; PDE, fosfodiesterasa; PLC-b, fosfolipasa C b; PGP, proteínas G pequeñas; KTnR, cinasas de tirosina no receptores; PI3-K, 3-cinasa del fosfatidil inositol. (+), estimulación; (-), inhibición. Elaborada a partir de las referencias 64-66.

\section{Revista Biomédica}




\section{Receptores de cinasa de tirosina y receptores acoplados a proteínas $G$.}

Un agonista (ligando que se une al receptor produciendo una respuesta funcional) estabiliza al receptor en su estado activo generando dicha respuesta en la célula, mientras que un antagonista (ligando que se une al receptor sin inducir una respuesta celular) se une a $\mathrm{R}$ o $\mathrm{R} *$ impidiendo que el receptor pase al estado activo. Este modelo es útil también para explicar el efecto de diversos ligandos como agonistas completos, agonistas parciales, antagonistas neutrales y agonistas inversos (para una revisión más amplia ver refs. 9 y 10).

Una vez activado el receptor, se inicia una serie de eventos intracelulares (cascadas de señalización) que modulan la función celular. Estos eventos dependen de la proteína $\mathrm{G}$ a la que se encuentre acoplado el receptor y de la maquinaria molecular con la que cuente la célula. La interacción del ligando con el receptor produce cambios conformacionales en el receptor, que a su vez modifican a la subunidad a de la proteína G. Este cambio conformacional repercute en la afinidad de la subunidad a por los nucleótidos de guanina, haciéndola más afín por GTP. Al intercambiar GDP por GTP, la subunidad a se activa y se desensambla tanto del receptor como del complejo bog para actuar así sobre su molécula blanco.

Dos ejemplos típicos de cascadas de señalización iniciadas por GPCR's son las que conducen a la formación de Ins $(1,4,5) \mathrm{P}_{3} / \mathrm{DAG}$ y AMPc como segundos mensajeros (figura 2). Para las subunidades aq la molécula blanco es la fosfolipasa C (PLC), enzima que hidroliza fosfoinosítidos de membrana generando Ins $(1,4,5) \mathrm{P}_{3}$ y DAG como segundos mensajeros. Para las subunidades as ó ai la molécula blanco es la adenilil ciclasa, enzima que cataliza la conversión de ATP a AMPc.

Ins(1,4,5) $\mathbf{P}_{3} / \mathbf{D A G}$. Esta vía es utilizada por los receptores acoplados a proteínas Gaq, como los receptores muscarínicos $\mathrm{M}_{1}, \mathrm{M}_{3}$ y $\mathrm{M}_{5}$ (abundantes en SNC y en el músculo liso y cardiaco), el receptor histaminérgico $\mathrm{H}_{1}$ (SNC, músculo liso, tracto gastrointestinal, sistemas genitourinario y cardiovascular)

\footnotetext{
${ }^{1}$ Ser, serina; Lis, lisina; Arg, arginina; Thr, treonina; X representa cualquier aminoácido.
}

y los adrenoceptores $a_{1}$ (SNC, músculo liso y cardiaco e hígado). Al formarse estos segundos mensajeros, por su naturaleza hidrofílica el Ins $(1,4,5) \mathrm{P}_{3}$ difunde al citosol mientras que el DAG permanece en la membrana plasmática debido a su naturaleza lipofílica. El Ins $(1,4,5)$ $\mathrm{P}_{3}$ se une a receptores ionotrópicos localizados el retículo sarcoendoplásmico, induciendo su apertura y, debido al gradiente de concentración existente, la salida al citosol de iones de $\mathrm{Ca}^{2+}$. Por su parte, el DAG, por sí mismo o en combinación con iones de $\mathrm{Ca}^{2+}$, activa a las isoformas nuevas o convencionales de la PKC, respectivamente. La PKC fosforila canales iónicos y enzimas en residuos de serina y treonina contenidos en secuencias específicas (por ejemplo, $\mathrm{Ser} / \mathrm{Thr}-\mathrm{X}-\mathrm{Arg}$ / Lis ó Arg/Lis-X-X-Ser/Thr) ${ }^{1}$ modulando así su función $(11,12)$.

AMPc. Los receptores involucrados en la cascadas de señalización del AMPc están acoplados a

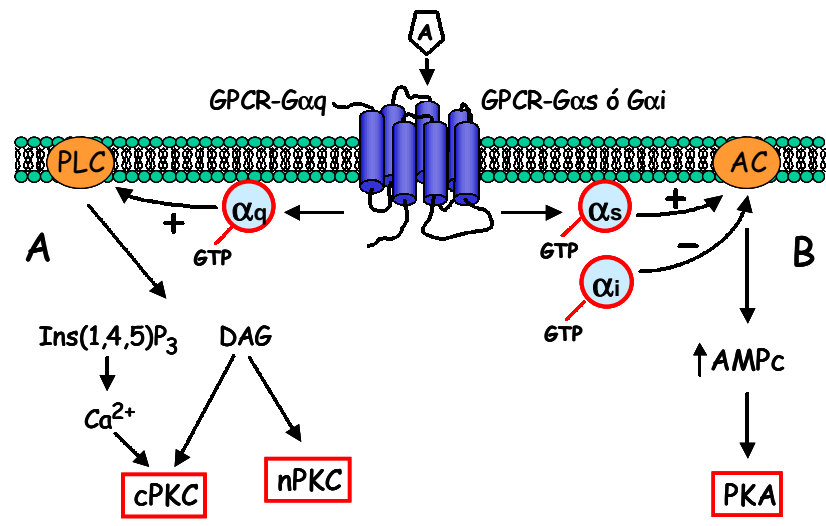

Figura 2. Vías de señalización clásicas inducidas por receptores acoplados a proteínas G (GPCR's). A) Al ser estimulado por el agonista (A) el receptor activa a su vez a la proteína $G$ correspondiente (Gaq, Gas ó Gai en este ejemplo). La subunidad aq activa a la fosfolipasa $\mathrm{C}$ la cual hidroliza fosfoinosítidos de membrana formando 1,4,5-trifosfato de inositol $\operatorname{Ins}(1,4,5) \mathrm{P}_{3}$ y diacilglicerol (DAG). El Ins(1,4,5) $\mathrm{P}_{3}$ aumenta la concentración intracelular de $\mathrm{Ca}^{2+}$ por vaciamiento de los depósitos intracelulares, mientras que el DAG activa a las isoformas nuevas de la cinasa $\mathrm{C}$ de proteína (nPKC's) o, en conjunto con iones de $\mathrm{Ca}^{2+}$, a las isoformas clásicas de la PKC (cPKC's). B) En el caso de los receptores acoplados a proteínas Gas o Gai, las subunidades a de estas proteínas estimulan (Gas) o inhiben (Gai) a la adenilil ciclasa (AC), enzima que produce AMP cíclico (AMPc) a partir de ATP. El AMPc activa a la cinasa A de proteína (PKA). Tanto la PKC como la PKA fosforilan a múltiples y diversas proteínas (receptores, canales iónicos, enzimas, factores de transcripción) regulando así el metabolismo celular.

Vol. 15/No. 1/Enero-Marzo, 2004 


\section{E Sánchez-Lemus, JA Arias-Montaño.}

proteínas Gas o Gai, las cuales inducen o inhiben respectivamente la formación del segundo mensajero. El receptor histaminérgico $\mathrm{H}_{2}(\mathrm{SNC}$, células gástricas, tejido cardiaco, músculo liso), la familia $\mathrm{D}_{1}$ de receptores dopaminérgicos (SNC), los adrenoceptores b (SNC, músculo liso y cardiaco, hígado) y numerosos receptores a hormonas, están acoplados a proteínas Gas. Los receptores muscarínicos $\mathrm{M}_{2}$ y $\mathrm{M}_{4}$ (SNC, músculo liso y cardiaco), el receptor histaminérgico $\mathrm{H}_{3}$ (SNC), la familia $\mathrm{D}_{2}$ de receptores dopaminérgicos (SNC) y los adrenoceptores $\mathrm{a}_{2}$ (arteriolas, glándulas salivales, intestinos, páncreas), se acoplan a proteínas Gai. La cascada de señalización continúa cuando el AMPc se une a las dos subunidades reguladoras de la cinasa $A$ de proteína (PKA), que se separan de las dos subunidades catalíticas. De manera similar a la PKC, las proteínas ( $v$. gr. canales iónicos o enzimas) que contengan residuos de serina o treonina en las secuencias específicas reconocidas por la PKA (Arg-Arg-X-Ser/Thró Arg$\mathrm{X}$-Arg-X-X-Ser/Thr) pueden ser fosforiladas, modificando así su función (figura 2B). Un ejemplo relevante es la transcripción de genes iniciada por la PKA al fosforilar a CREB (proteína de unión a CRE, nombre dado a una secuencia de DNA localizada en la región promotora del inicio de la transcripción) $(11,13)$.

\section{SEÑALIZACIÓN INTRACELULAR POR RECEPTORES CON ACTIVIDAD DE CINASA DE TIROSINA (RTK'S).}

\section{RECEPTORES.}

Estructuralmente los RTK's difieren de manera considerable de los receptores acoplados a proteínas $\mathrm{G}$ (GPCR's). Los RTK's son proteínas de membrana de 600 a 1100 aa, con un solo dominio transmembranal y dominios catalíticos con actividad intrínseca de cinasa de tirosina. Los RTK's son activados predominantemente por factores de crecimiento como el EGF (factor de crecimiento epidérmico), el PDGF (derivado de plaquetas) y el ILGF-1 (factor de crecimiento semejante a insulina tipo 1), aunque algunos receptores a citocinas y hormonas son también RTK's (11).

La región amino terminal de estas proteínas se orienta hacia el lado extracelular y los receptores típicos poseen dos dominios ricos en cisteínas (receptores tipo I y II), o bien 5 ó 3 repetidos de dominios semejantes a los presentes en las inmunoglobulinas (receptores tipo III y IV respectivamente) (14). En varios casos no se conoce con certeza la función de los residuos de cisteína, pero en algunos receptores (a insulina o EGF por ejemplo) participan de manera crucial en la formación de dímeros (15). Además, el extremo amino terminal presenta también sitios de glicosilación que pueden regular la unión del ligando al receptor.

El extremo carboxilo terminal se orienta hacia el interior de la célula y estructuralmente posee dos componentes importantes que definen la cascada de señalización intracelular: 1) un dominio con actividad de cinasa de tirosina, y 2) un número importante de residuos de tirosina, susceptibles de ser fosforilados, lo que conduce a la activación de diversas proteínas mediante el mecanismo que se describe a continuación (figura 3A).

\section{SEÑALIZACIÓN.}

Activación del receptor. Requiere tres pasos secuenciales: 1) unión del ligando al receptor, 2) la dimerización del receptor, y 3) la autofosforilación del receptor en residuos de tirosina. La unión del ligando induce cambios conformacionales en el receptor, los cuales favorecen su interacción con otro receptor para formar un dímero. La unión del ligando activa también al dominio de cinasa de tirosina del receptor, por lo que al formar el dímero cada receptor fosforila múltiples residuos de tirosina de su homólogo (figura 3B). A este fenómeno se le conoce como autofosforilación, ya que en ese momento ambas moléculas se encuentran formando un nuevo receptor dimérico, que se fosforilaría a sí mismo. Sin embargo, algunos autores prefieren denominar a este proceso transfosforilación (14).

Una vez activado el receptor, la señalización continúa mediante los residuos de tirosina fosforilados, que se contituyen en el sitio de unión y activación de diversas proteínas. Las proteínas que pueden ser activadas por fosfotirosinas (como la PLC-g) requieren tener en su estructura dominios de reconocimiento de las mismas. Estos dominios están altamente conservados y son conocidos como SH2 (región 2 de homología a Src, por haber sido descrito inicialmente en la proteína Src

\section{Revista Biomédica}




\section{Receptores de cinasa de tirosina y receptores acoplados a proteínas $G$.}

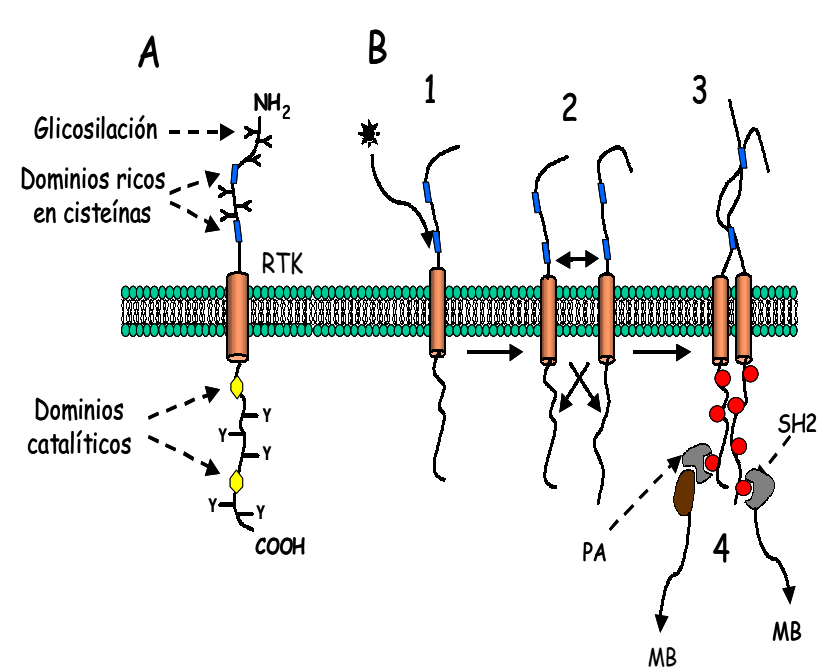

Figura 3. Mecanismo de activación de los receptores con actividad de cinasa de tirosina (RTK's). A) Representación esquemática de la estructura del receptor para EGF (factor de crecimiento epidérmico), característica de los RTK's del grupo I con un solo dominio transmembranal, el extremo amino terminal orientado al lado extracelular y el carboxilo al intracelular. El extremo amino se encuentra muy glicosilado y expresa dos dominio ricos en cisteínas; en el extremo carboxilo se encuentran residuos de tirosina (Y) y los dos dominios catalíticos con actividad de cinasa de tirosina. B) La unión del ligando al receptor (1) induce la dimerización (2) y la autofosforilación en los residuos de tirosina (3). Los residuos de tirosina fosforilados sirven como centros de activación para proteínas con dominios SH2 (4) o bien como sitios de unión para proteínas adaptadoras (PA), que continúan la señalización hacia las moléculas blanco (MB).

(figura 3B). Los dominios SH2 se unen no sólo a las fosfotirosinas sino también a ciertos aminoácidos adyacentes a las mismas. Esta característica le proporciona especificidad a la activación por fosfotirosinas de las proteínas de señalización, ya que una proteína con dominios $\mathrm{SH} 2$ sólo se activará si reconoce a la fosfotirosina con la secuencia correcta de aminoácidos a ambos lados. Por ejemplo, el receptor para el factor de crecimiento derivado de plaquetas (PDGF) activa a la 3-cinasa de fosfatidil inositol (PI3K) cuando ésta se une a las fosfotirosinas 708 y 719 , mientras que la PLC-g se activa por unión a las fosfotirosinas 977 y 989 (16).

Interesantemente, existe un mecanismo alterno por el cual pueden activarse proteínas que carecen de dominios SH2. Este proceso requiere de pequeñas proteínas adaptadoras que poseen dominios $\mathrm{SH} 2$ así como dominios de unión a otras proteína de señalización, de manera tal que dichas proteínas adaptadoras se unen a las fosfotirosinas del receptor y posteriormente se acoplan y activan a otras proteínas (figura 3B) (11).

Ras y cascada de ERK's. Frecuentemente la activación de RTK's genera señales que inducen proliferación y diferenciación celulares a través de las cinasas de proteína activadas por mitógenos (mitogenactivated protein kinases; MAPK's), más recientemente denominadas cinasas reguladas por señales extracelulares (extracellular signal-regulated kinases; ERK's). El intermediario que conecta a la cascada de señalización generada por la activación de un RTK con las ERK's es la proteína Ras, que puede unir nucleótidos de guanina y que posee también actividad de GTPasa. Ras es una GTPasa pequeña (similar a la subunidad de la proteína G, pero con actividad 100 veces menor), que es regulada por proteínas liberadoras de nucleótidos de guanina (GNRP's) y por proteínas estimuladoras de la actividad de GTPasa (GAP's). Las proteínas liberadoras de nucleótidos de guanina activan a Ras al favorecer el intercambio de GDP por GTP, mientras que las proteínas estimuladoras de la actividad de GTPasa finalizan la señalizaciónal aumentar la actividaddeGTPasa intrínseca a Ras y que hidroliza el GTP unido a GDP (figura 4) (17). Es importante señalar que tanto las proteínas liberadoras de nucleótidos de guanina como las estimuladoras de la actividad de GTPasa son proteínas que se activan por unión a fosfotirosinas presentes en RTK's activados.

En el estado activo, Ras activa a la cascada de las ERK's al unirse y activar a Raf, una cinasa de serina/treonina que a su vez fosforila y activa a la cinasa de ERK/MAPK (denominada MEK), enzima que fosforila residuos de serina/treonina y de tirosina. La activación de ERK's requiere de su fosforilación en un residuo de treonina y en uno de tirosina, separados únicamente por un aminoácido. Esta función sólo puede ser realizada por una enzima altamente especializada, por lo que se considera que MEK es la enzima limitante en la activación de ERK's, haciendo altamente específico este proceso. Finalmente la ERK fosforilada pasa del citoplasma al núcleo y regula por fosforilación a otras cinasas y 
E Sánchez-Lemus, JA Arias-Montaño.
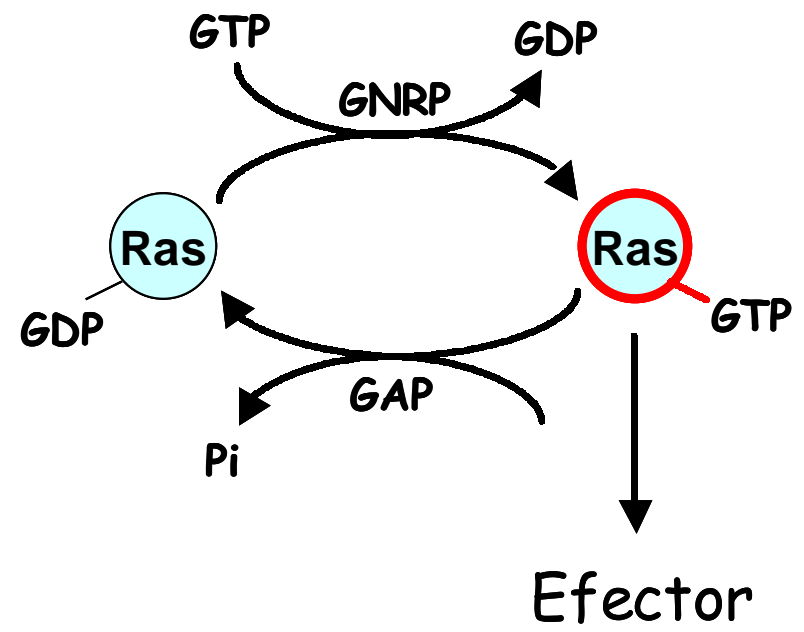

Figura 4. Activación de la proteína Ras. El mecanismo es similar a la activación de la subunidad a de una proteína $G$, con intercambio de GDP por GTP, favorecido por proteínas liberadoras de nucleótidos de guanina (GNRP). La inactivación se debe a la hidrólisis del GTP a GDP, debida a la actividad de GTPasa intrínseca a Ras. Este último proceso es acelerado por proteínas estimuladoras de la actividad de GTPasa (GAP).

a proteínas reguladoras de la transcripción (figura 5) (18-19). Dado que MEK es la cinasa de ERK's (o MAPK's), también se le identifica como MAPKK (cinasa de MAPK's). De manera análoga, como Raf es la cinasa de MEK (oMAPKK), también se le denomina MAPKKK (cinasa de la cinasa de MAPK's).

JAK's/STAT's. Otro mecanismo que sigue a la estimulación de los RTK's es la activación de las cinasas Janus (JAK's) y de los transductores y activadores de la señal de transcripción (STAT’s), descrito más recientemente (en la década de los 90, a diferencia de las ERK's que fueron descritas en los 80). El mecanismo de activación es relativamente sencillo, ya que al unirse el ligando a un RTK que tenga JAK's unidas a su extremo carboxilo terminal, se induce la dimerización y la autofosforilación del dímero, así como la fosforilación de las JAK's asociadas. Este evento recluta a los STAT's que se unen a fosfotirosinas a través de su dominio $\mathrm{SH} 2$ y se activan por fosforilación en residuos de tirosina, lo que induce su dimerización y translocación al núcleo celular, donde se unen a factores de transcripción y/o al DNA en sitios específicos activando así la transcripción de genes (para una revisión más amplia ver refs. 20-22).

\section{TRANSACTIVACIÓN DE RTK's.}

Como se mencionó antes, las respuestas celulares mitogénicas son generadas principalmente por estimulación de RTK's que activan la vía Ras ${ }^{\circledR}$ Raf ( MEK @ ERK, la cual ha sido ampliamente estudiada. La activación de la vía por GPCR's había sido poco estudiada hasta hace una década, conociéndose sólo que el mecanismo involucraba proteínas $\mathrm{G}$ sensibles a la toxina de Bordetella pertusis (ai/o), y que dependía fuertemente del complejo bog de la proteína $\mathrm{G}$ y de cinasas de tirosina no identificadas (1-3). No obstante, tan sólo un par de años después el número de investigaciones orientadas a este tópico creció significativamente y varios estudios indicaron que en ausencia de ligandos para RTK's, la activación de receptores acoplados a proteínas Gaq(GPCR's-Gaq) inducía la fosforilación de la proteína Shc y la formación del complejo Shc-Grb2 (23-25), siendo ambas

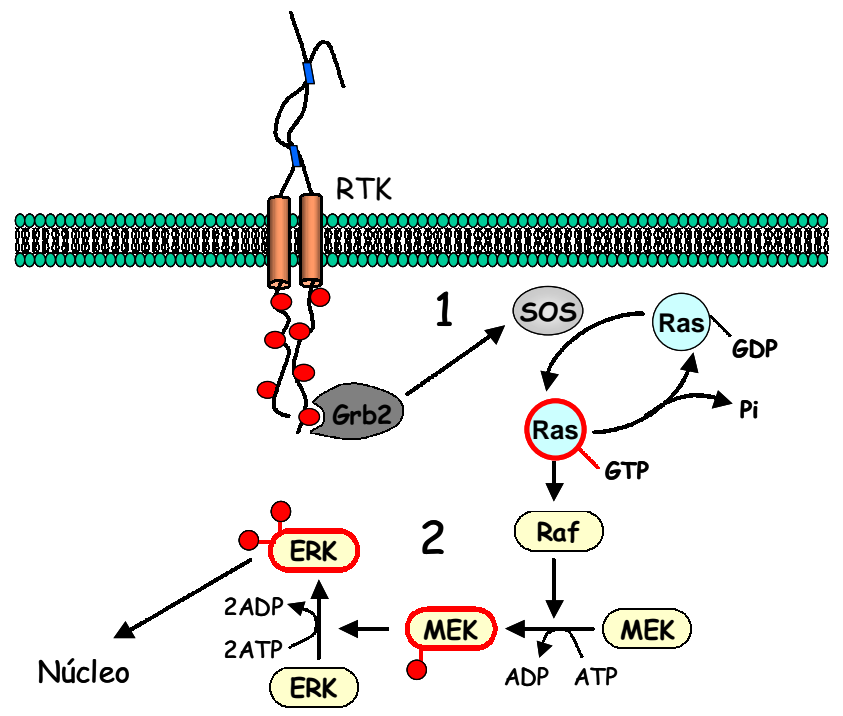

Figura 5. Activación de las cinasas de proteína activadas por señales extracelulares (ERK's). 1) Una vez que un receptor con actividad de cinasa de tirosina (RTK) se ha dimerizado y autofosforilado, las fosfotirosinas reclutan a Grb2, una proteína acopladora que posee dominios $\mathrm{SH} 2$, los cuales sirven de sustrato para la unión de secuencias ricas en prolina presentes en el extremo carboxilo terminal de la proteína SOS, una proteína liberadora de nucleótidos de guanina. La proteína SOS induce la activación de la proteína Ras, al favorecer el cambio al estado activo, unida a GTP. 2) La proteína Ras-GTP se une y activa a la proteína Raf, una cinasa de serina/treonina. A su vez la proteína Raf fosforila y activa a MEK, una cinasa de serina/treonina y tirosina, la cual fosforila y activa a diferentes subtipos de ERK's, que se traslocan al núcleo celular donde fosforilan factores de transcripción que modifican la expresión de genes.

\section{Revista Biomédica}




\section{Receptores de cinasa de tirosina y receptores acoplados a proteínas $G$.}

proteínas adaptadoras involucradas en la activación de la vía Ras-Raf-MEK-ERK a través de su unión a las fosfotirosinas de un RTK activado (figuras 5 y 6), sugiriendo que el RTK había sido activado sin necesidad de interactuar con su ligando.

La activación de un RTK en ausencia del ligando respectivo no era un concepto completamente nuevo. Anteriormente los grupos de Greenberg, de Rahmsdorf, de Kruijer y de Herrlich, entre otros, habían mostrado que el receptor para el factor de crecimiento epidérmico (EGF-R) podía ser regulado al activarse canales de $\mathrm{Ca}^{2+}$ dependientes de voltaje (26), y que el EGF-R y los receptores para insulina y para el factor de crecimiento derivado de plaquetas eran activados por la radiación ultravioleta (27-29). Sin embargo, el hallazgo de que los GPCR's, la familia más grande de receptores membranales, podía inducir la activación de RTK's y por lo tanto generar señales mitogénicas, condujo a una oleada de trabajos enfocados a discernir los puntos clave de este fenómeno, denominado ahora transactivación.

El fenómeno de transactivación fue elegantemente expuesto por el grupo de Ullrich (30) utilizando la línea celular de fibroblastos Rat-1 que expresa diversos GPCR's y al EGF-R. En este estudio se muestra que la activación de GPCR's para endotelina, ácido lisofosfatídico y trombina indujo en todos los casos la fosforilación del EGF-R en ausencia de ligando para este último. Además, dicha fosforilación se bloquea totalmente si se transfecta un EGF-R mutante que carece del dominio citoplasmático, es decir un receptor que no es capaz de formar dímeros funcionales, lo cual también eliminó la idea de que en estos casos el receptor se fosforilaba sin necesidad de dimerizarse. La fosforilación delEGF-R fue también prevenida al incubar a las células con tirfostín AG-1478, un inhibidor selectivo de la actividad de cinasa de tirosina del EGFR. En conjunto, estos datos indican que existen fenómenos intracelulares originados por la activación de GPCR's, que inciden sobre RTK's induciendo la dimerización y autofosforilación necesarias para su activación.

Lo anterior abrió un campo de estudio muy amplio con preguntas como: a) si la transactivación era un fenómeno restringido a determinado tipo o tipos celulares y/o a ciertas especies; b) si la activación de un GPCR particular transactivaba específicamente a un RTK determinado o si cualquier GPCR podía transactivar a cualquier RTK que se encuentre en el área donde se promovía la cascada de señalización; c) si todos los GPCR's podían inducir transactivación o sólo los GPCR's-Gaq; y de manera relevante y obligada, d) ¿cuáles eran las moléculas involucradas en este fenómeno?

\section{A) Amplitud del fenómeno de} transactivación. El fenómeno de transactivatión ocurre en diferentes especies y tipos celulares. Por mencionar sólo algunos ejemplos, se ha observado transactivación en la rata: en la línea celular Rat-1 de fibroblastos (30), en cultivo primario de células de músculo liso vascular (31-32); en el humano: en las líneas celulares de próstata PC12 (33) y PC3 (34), en la línea celular T84 de colon (35) y en la línea celular $\mathrm{HaCaT}$ de queratinocitos (36); en el ratón: en cultivo primario de astrocitos y en la línea celular L de músculo esquelético (37); y en el mono: en la línea celular COS7 de riñón del mono verde africano (36).

Como puede advertirse, una cantidad importante de las evidencias del fenómeno de transactivación ha sido obtenida en líneas celulares $(30,34,36,37)$, las cuales permiten estudiar diversos fenómenos intracelulares con la gran ventaja de conocer los tipos de receptores, canales iónicos y vías de señalización presentes, y de aislar un efecto usando fármacos selectivos para bloquear un receptor, un canal o una vía de señalización, además de la relativa facilidad para transfectar material genético que codifique para proteínas específicas. El uso de líneas celulares conlleva sin embargo la desventaja de que se estudian células con alteraciones en su ciclo de vida que las hace inmortales, por lo que no es posible descartar que presenten otras alteraciones en su funcionamiento. No obstante, las líneas celulares generan información que frecuentemente es confirmada en otras preparaciones. En particular, para el fenómeno de transactivación destaca el que muchas líneas celulares utilicen esta vía de señalización, ya que podría ser uno de los factores que participen en 
E Sánchez-Lemus, JA Arias-Montaño.

la proliferación celular desmedida, y que por lo tanto a través del bloqueo de GPCR's determinados pueda controlarse el crecimiento tumoral.

B) Especificidad de la transactivación. No sólo se ha observado el fenómeno para el EGF-R sino también para otros receptores a factores de crecimiento. Por ejemplo, en células de cultivo primario de músculo liso vascular el receptor para el factor de crecimiento derivados de plaquetas (PDGFR) se fosforila en ausencia de ligando si se estimulan receptores a angiotensina II, acoplados a proteínas $\mathrm{G}$ (31). De manera análoga, el receptor para el factor 1 de crecimiento semejante a insulina (ILGF-1-R), así como el sustrato-1 del receptor de insulina (IR-S1) y la PLC-g(moléculas de señalización para el ILGF1-R) se encuentran fosforilados después de la exposición a trombina (32). Por ello se ha propuesto que la transactivación se ejerce sobre diferentes RTK's, representando una nueva dimensión para la señalización a través de GPCR's.

Además, existe evidencia de que la estimulación de un GPCR no activa de manera específica a un solo tipo de RTK. En este sentido, Herrich y col. (37) mostraron que la activación de receptores para el ácido lisofosfatídico induce fosforilación del PDGF$R$ en células $L$ (que expresan el PDGF-R, pero no el EGF-R), mientras que en células COS-7 (que expresan el EGF-R pero no el PDGF-R), el mismo agonista induce fosforilación del EGF-R. Es interesante señalar que el efecto muestra preferencia por diferentes RTK's, ya que cuando se encuentran presentes ambos receptores, PDGF-R y EGF-R, sólo se activa este último. Lo anterior plantea que los GPCR's pueden transactivar a diferentes RTK's y que aun cuando podrían tener preferencia por alguno de ellos, la carencia de un RTK dado pueda ser suplida por un RTK similar, de tal manera que no se anule la inducción de la señal mitogénica mediada por RTK's.

C) Transactivación y proteínas G. El establecer si GPCR's diferentes de los acoplados a Gaq inducían también la activación de RTK's podía dar indicios sobre las moléculas involucradas en la transactivación, al determinar los aspectos comunes en las cascadas de señalización de los diferentes GPCR's. Es por ello que uno de los primeros objetivos fue determinar si otras proteínas $\mathrm{G}$ podían inducir transactivación, y en este sentido varios estudios han mostrado que los GPCR's acoplados a proteínas Gai (GPCR's-Gai) son también capaces de transactivar a RTK's $(36,38,39)$. En contraste, hasta la fecha no existe evidencia concluyente de que los GPCR's acoplados a proteínas Gas (GPCR's-Gas) induzcan fosforilación de RTK's, excepto para el caso particularmente interesante del adrenoceptor $\mathrm{b}_{2}$. Este receptor se acopla normalmente a proteínas Gs por lo que al ser estimulado se activa la PKA (figura 2B), que fosforila al mismo receptor promoviendo así su acople a proteínas Gai (40). De esta manera, aun cuando la activación de los adrenoceptores $\mathrm{b}_{2}$ induce transactivación en células COS-7, ésta es totalmente dependiente de proteínas Gai (41). Se ha mostrado que este fenómeno de estimulación dual lo utilizan tanto los adrenoceptores b como los receptores para el péptido intestinal vasoactivo (VIP) presentes en células de los acinos pancreáticos y del conducto submandibular, por lo que se ha propuesto que puede

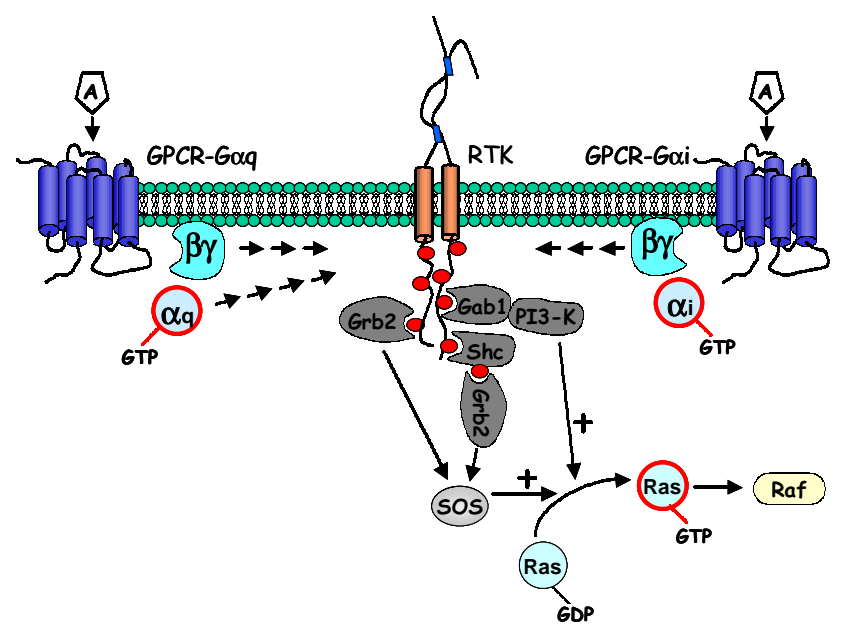

Figura 6. Mecanismos de transactivación de RTK's por receptores acoplados proteínas Gaq y Gai. La activación de proteínas Gaq induce transactivación de RTK's a través de procesos mediados tanto por la subunidad aq como el complejo bo, mientras que los receptores acoplados a proteínas Gai inducen la transactivación sólo a través de los complejos bg. Una vez que el RTK se autofosforila, la cascada de señalización es idéntica a la que seguiría un RTK activado por ligando, con la unión de proteínas que posean dominios $\mathrm{SH} 2$ a las fosfotirosinas del receptor y la activación subsecuente de la vía RasRafMEKERK's.

\section{Revista Biomédica}


Receptores de cinasa de tirosina y receptores acoplados a proteínas $G$.

ser un mecanismo que la célula utiliza normalmente (42). Si esta idea es cierta, es probable entonces que diversos GPCR's acoplados a proteínas Gas puedan activar vías mitogénicas por transactivación a través de la estimulación dual.

D) Cascada de señalización involucrada en la transactivación. El que dos proteínas G diferentes (Gaqy Gai) activaran la misma vía mitogénica sugería dos posibilidades: 1) De manera semejante a la subunidad a de la proteína Gaq, el complejo bog de las proteínas $\mathrm{Gai}$ activaba a la fosfolipasa $\mathrm{C}$ originando Ins $(1,4,5) \mathrm{P}_{3}$ y DAG, induciendo la activación de la PKC (figura 2A), lo que podía dirigir la señalización hacia la transactivación de RTK's; 2) los complejos bo de ambos tipos de receptores (GPCR's-Gaq y -Gai) podrían inducir, directamente o a través de otras moléculas, la dimerización y autofosforilación de RTK's.

Para la primera posibilidad es relevante que en células CHO la expresión aumentada de las subunidades aq, ai ó a s no induce por sí misma la activación de ERK2 (43). Sin embargo, en células HEK-293 la fosforilación de ERK1/2 producida por activación de adrenoceptores $\mathrm{a}_{1 \mathrm{~B}}$ no se modifica por el secuestro del complejo bo (44) lo cual sugiere la participación de la subunidad a q. Otro aspecto en este sentido radica en la participación de la $\mathrm{PKC}$, que resulta relativamente incierta. Hawes y col. (43) y Tsai y col. (45) demostraron en diferentes tipos celulares (células HEK-293 de embrión humano, COS-7 de mono verde africano, y $\mathrm{CHO}$ de hámster chino), que la activación de la PKC era imprescindible para la transactivación del EGF-R y la activación de ERK's generadas por la estimulación de los receptores acoplados a proteínas Gaq $\left(\mathrm{M}_{1}\right.$ para acetilcolina y adrenoceptores $a_{1}$ ). En contraste, Keely y col. (35) observaron que en células T84 la activación de ERK's generada por carbacol (un agonista muscarínico inespecífico) es mimetizada por un activador de la PKC pero no es afectada por un inhibidor de la misma. Además, en células NIH-3T3 transfectadas con el receptor muscarínico $\mathrm{m}_{1}$, la activación de Raf-1 y ERK2 inducida por carbacol disminuye en un 20-50\% en presencia de un inhibidor de la PKC, y no afecta la síntesis de DNA (46).

La segunda posibilidad, un efecto directo de los complejos bg de las proteínas G-aq y G-ai, se ve apoyada por la observación de que la expresión aumentada de complejos bg incrementa la fosforilación del EGF-R en células COS-7 (47), mientras que el uso de moléculas que secuestran al complejo bg (v.gr. bARKCT) reduce sustancialmente la transactivación inducida por receptores para ácido lisofosfatídico (37), $\mathrm{D}_{2}$ para dopamina, $\mathrm{A}_{1}$ para adenosina (2), $\mathbf{M}_{2}$ para acetilcolina $(2,3)$ y adrenoceptores $\mathrm{a}_{2}(3)$; pero no modifica la activación de ERK's inducida por receptores $\mathrm{a}_{1 \mathrm{~B}} \mathrm{y} \mathrm{M}_{1}$ (43). El primer grupo son receptores que ejercen su efecto mediante proteínas Gai (excepto aquellos para el ácido lisofosfatídico, acoplados también a proteínas Gaq (36) y los segundos corresponden a GPCR's-Gaq.

En resumen, estas evidencias sugieren que los receptores acoplados a proteínas Gai inducen transactivación a través de los complejos bo, y que los receptores acoplados a proteínas Gaq pueden hacerlo tanto a través de la subunidad aq como a través de los complejos bog en función de la maquinaria célular; es decir, el efecto depende de la variedad de moléculas presentes (receptores, proteínas efectoras y cinasas como la PKC, figura 6). Así, en un estudio realizado en células COS-7 la estimulación simultánea de receptores para bombesina (acoplados a proteínas Gaq) y $\mathrm{M}_{2}$ para acetilcolina (acoplados a proteínas Gai), resultó en un efecto aditivo en la autofosforilación del EGF-R (36), sugiriendo que en este tipo celular la acción de los GPCR's-Gaq depende de la subunidad aq, que se suma al efecto de los complejos bo producidos por la activación de GPCR's-Gai.

Un descubrimiento importante tuvo lugar en 1999, cuando se demostró que la transactivación del EGF-R por receptores acoplados a proteínas Gaq o Gi involucraba la liberación al medio extracelular de un ligando endógeno $(34,48)$. En la membrana celular el ligando se encuentra asociado a heparina (HBEGF), y el complejo puede ser hidrolizado por metaloproteasas (dependientes $\mathrm{Ca}^{2+} \mathrm{o} \mathrm{Zn}^{2+}$ ) liberando así al EGF al medio extracelular (figura 7), donde puede activar a receptores presentes en la misma célula 


\section{E Sánchez-Lemus, JA Arias-Montaño.}

(transactivación autócrina) o en células vecinas (transactivación parácrina). La cantidad de EGF liberado debe ser muy pequeña ya que no es posible medirla por métodos convencionales como Western blot (45) y el efecto de la transactivación sobre la fosforilación del EGF-R y la activación de proteínas adaptadoras (como Shc y Grb2), es mucho menor al que se obtiene utilizando EGF exógeno a una concentración de $0.3 \mathrm{nM}(30,36), 8$ veces menor que la concentración efectiva media $\left(\mathrm{EC}_{50}\right)$ del EGF para inducir dimerización del receptor $(2.5 \mathrm{nM})$ (49). Sin embargo, aunque la concentración extracelular de EGF sea mucho menor que la $\mathrm{EC}_{50}$ y que la concentración fisiológica reportada (3-5 nM) (50), el EGF podría activar a los receptores cercanos al sitio de liberación, funcionando eficientemente en los microdominios adyacentes.

Sin embargo, para la transactivación de los receptores para los factores de crecimiento semejante a insulina y derivado de plaquetas no se ha descrito un proceso de liberación de ligandos. Es posible que la transactivación de estos receptores no requiera de la formación de dímeros, o bien que la dimerización sea independiente de ligandos, mediante sus dominios con actividad de cinasa de tirosina presentes en el extremo amino terminal, como ha sido demostrado in vitro para el receptor para EGF (51).

Una vez que el RTK ha sido estimulado por transactivación, la señalización parece ser idéntica a la generada por la unión del ligando correspondiente. Esto es, el receptor activado une proteínas con dominios SH2 como Shc, Grb2, Gab1 y Src. En particular Shc y Grb2 participan en la activación de la proteína SOS (una GNRP, proteína liberadora de nucleótidos de guanina) que induce la activación de Ras e inicia la cascada Ras ${ }^{\circledR}$ Raf ${ }^{\circledR}$ MEK $®$ ERK (52) (figuras 5 y 6), mientras que Gab1 puede activar a la 3-cinasa de fosfatidil-inositol (PI3-K), que a su vez activa a Ras por un mecanismo aún no descrito (36, 53) (figura 6). Por otra parte, Src es una cinasa de tirosina que se activa al unirse a las fosfotirosinas de RTK's y que induce la transcripción de genes. Aunque no se conoce la vía completa, recientemente un ingenioso estudio con cocultivos mostró que Src se activa antes de la fosforilación

\section{Revista Biomédica}

del EGF-R y después de la activación de la proteína Gai, y que su participación es determinante para la hidrólisis del complejoEGF-heparina, además de modular la activación de ERK's a nivel de la cinasa $\operatorname{MEK}(41,48)$ (figura 7). Esto situa a la cinasa de tirosina Src como un mediador muy importante para la activación de ERK's a través de receptores acoplados a proteínas $\mathrm{G}$ ya que la modula a dos niveles, en la activación de MEK y en la liberación de EGF a partir del complejo EGF-heparina.

Por otra parte, inicialmente se consideró que la endocitosis de los RTK's dependiente de b-arrestinas y de clatrina formaba parte de los mecanismos celulares para apagar la señal iniciada por la unión del ligando al receptor. Sin embargo, evidencias más recientes muestran que la internalización de los RTK's puede, además de atenuar la señal, desencadenar y modular otras cascadas de señalización $(54,55)$. Dado que algunos receptores acoplados a proteínas $\mathrm{G}$ como los adrenoceptores $\mathrm{b}_{2}(40,41)$, para ácido lisofosfatídico (47), muscarínicos (56) y para opioides $\mu$ y $d(57)$, requieren internalizarse para activar eficazmente a las ERK's, se sugirió que la endocitosis

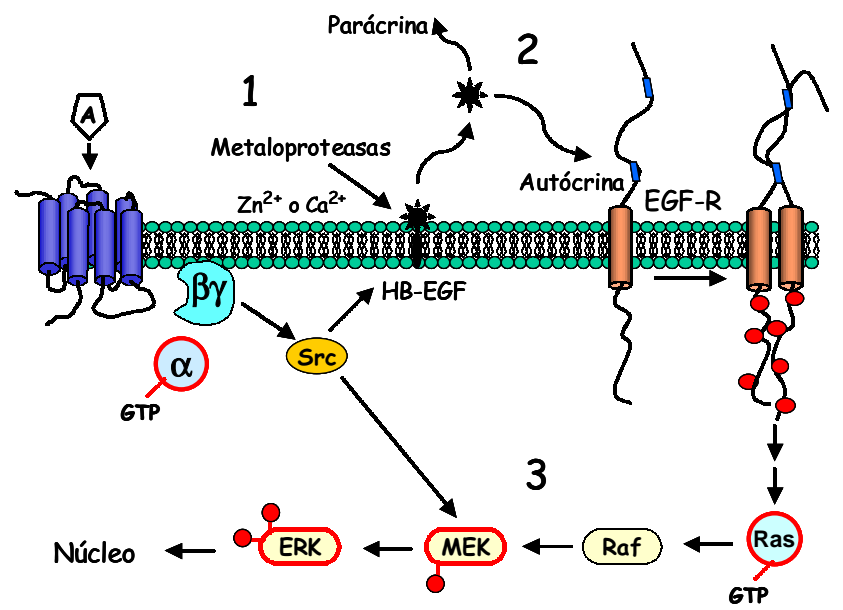

Figura 7. Transactivación del receptor para el factor de crecimiento epidérmico (EGF-R) por liberación de EGF inducida por la activación de receptores acoplados a proteínas G. 1) Al activarse receptores acoplados a proteínas Gaq o Gai, los complejos bo de estas proteínas activan a la cinasa de tirosina $\mathrm{Src}$, la cual activa a su vez a metaloproteasas dependientes de $\mathrm{Ca}^{2+}$ o $\mathrm{Zn}^{2+}$ las que al actuar sobre el complejo EGF-heparina (HB-EGF), presente en la membrana celular, inducen el desprendimiento del EGF al medio extracelular. 2) El EGF liberado activa a receptores localizados en la misma célula (transactivación autócrina) o en células vecinas (transactivación parácrina). 3) La señalización prosigue hacia la vía RasRafMEKERK's, que puede ser también modulada directamente por Src. 


\section{Receptores de cinasa de tirosina y receptores acoplados a proteínas $G$.}

de los receptores acoplados a proteínas $\mathrm{G}$ podría ser necesaria para la transactivación de RTK's. En relación a este punto, se mostró que la transactivación por adrenoceptores $b_{2}$ del EGF-R no requería de la endocitosis del receptor $\mathrm{b}_{2}$ para la dimerización y autofosforilación del RTK, pero que la endocitosis (mediada por b-arrestinas y clatrina) del complejo formado por ambos receptores era imprescindible para la activación de ERK's (41) (fig. 8).

En este mismo sentido y en relación a la participación de Src en la transactivación, la actividad de cinasa de Src es necesaria para la internalización del adrenoceptor $\mathrm{b}_{2}$ (58) y para ensamblar el complejo adrenoceptor b,/EGF-R (41). Además, Src podría regular, mediante fosforilación, el arreglo de la clatrina (59). Sin embargo, el mecanismo de endocitosis conjunta de un GPCR con un RTK transactivado parece no ser relevante para aquellos GPCR's que no se regulan por endocitosis como el adrenoceptor $a_{1}$, que induce la dimerización y autofosforilación del EGF-R y activa ERK's aún en presencia de un inhibidor de la endocitosis (48).

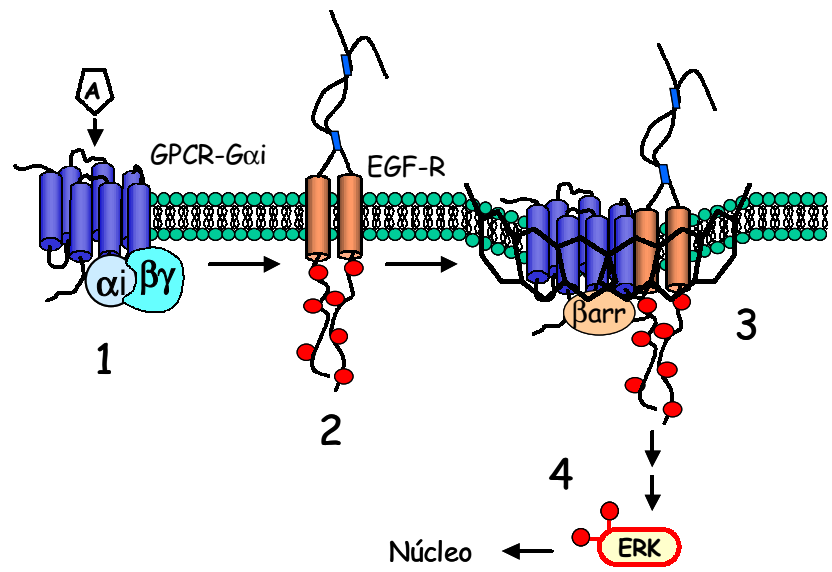

Figura 8. Endocitosis de receptores membranales y transactivación. La transactivación por adrenoceptores $b_{2}$ del receptor para el factor de crecimiento epidérmico (EGF) requiere de la internalización del complejo receptor a EGF-adrenoceptor $\mathrm{b}_{2}$, mediada por b-arrestinas y clatrina. 1) La activación del adrenoceptor $\mathrm{b}_{2}$ induce su fosforilación por cinasas de receptores acoplados a proteínas ó GRK's, lo que permite la unión de barrestinas (arr) a los residuos de serina/treonina fosforilados. 2) Activación del RTK, al cual se le asocian proteínas adaptadoras como Shc. 3) Formación del complejo GPCR-RTK y reorganización de la clatrina para formar el endosoma conteniendo ambos receptores. 4) Endocitosis y generación de la vía de activación de ERK's.

\section{CONCLUSIONES.}

La evidencia actual indica que la transactivación de RTK's por receptores acoplados a proteínas $\mathrm{G}$ y la generación de las señales mitogénicas que sigue a dicha activación presentan las siguientes características:

a) Tiene lugar en diferentes tejidos de diversas especies, así como en tejidos nativos y en líneas celulares;

b) No presenta especificidad, pero sí selectividad para ciertos RTK's;

c) Se debe a la activación de receptores acoplados a proteínas Gai y Gaq. En el caso de las proteínas Gai el efecto se debe a la acción de los complejos bog, mientras que para las proteínas Gaq el efecto está mediado tanto por las subunidades aq como por los complejos bog.

Una vez transactivado, el RTK inicia una cascada de señalización idéntica a la generada por activación exógena, es decir, activación de ERK's a través de la vía Ras ${ }^{\circledR}$ Raf $\AA$ MEK $\AA$ ERK, siendo en algunos casos necesaria la endocitosis mediada por barrestinas y clatrina.

Un mecanismo interesante y relevante de regulación de las cascadas de señalización generadas por activación de receptores acoplados a proteínas $\mathrm{G}$, corresponde a la llamada señalización cruzada (cross-talk), donde una o más cascadas pueden entrecruzarse y modificarse entre sí (ya sea estimulándose o inhibiéndose). Este mecanismo confiere a la señalización por receptores acoplados a proteínas $\mathrm{G}$ una modulación precisa y fina, como ha sido expuesto en diferentes revisiones (ver por ejemplo ref. 60-65). No obstante, el conocimiento del fenómeno de transactivación ha aumentado y profundizado nuestra comprensión de la regulación de los efectos inducidos por la activación de receptores acoplados a proteínas $\mathrm{G}$, que van más allá de la formación de segundos mensajeros.

Se ha sugerido que el receptor para EGF, así como otros receptores a factores de crecimiento, participan en la patogénesis del cáncer (particularmente de las neoplasias de mama, esófago, páncreas, ovario y pulmón), ya que diversos estudios clínicos han mostrado que el tejido afectado presenta una 


\section{E Sánchez-Lemus, JA Arias-Montaño.}

expresión aumentada tanto de los receptores como de los ligandos correspondientes, lo que daría lugar a una fuerte estimulación autocrina. Los mecanismos por los que el EGF induce el crecimiento de tumores incluyen inhibición de la apoptosis (muerte celular programada), inducción de la angiogénesis y estimulación de la motilidad y adhesión celulares (66). La gran diversidad de receptores acoplados a proteínas $\mathrm{G}$ y su amplia distribución, sumadas al importante papel que tienen los factores de crecimiento como el EGF en la proliferación celular, sugieren que la transactivación de RTK's puede estar involucrada en la tumorigénesis y metástasis en múltiples tejidos, por lo que la investigación de dicho mecanismo tiene aún un amplio campo de desarrollo.

\section{REFERENCIAS.}

1.- van Corven EJ, Hordijk PL, Medema RH, Bos JL, Moolenaar WH. Pertussis toxin-sensitive activation of p21ras by $\mathrm{G}$ protein-coupled receptor agonists in fibroblasts. Proc Natl Acad Sci USA 1993; 90: 1257-61.

2.- Faure M, Voyno-Yasenetskaya TA, Bourne HR. cAMP and subunits of heterotrimeric $G$ proteins stimulate the mitogen-activated protein kinase pathway in COS-7 cells. J Biol Chem 1994; 269: 7851-4.

3.- Koch WJ, Hawes BE, Allen LF, Lefkowitz RB. Direct evidence that Gi-coupled receptor stimulation of mitogenactivated protein kinase is mediated by $\mathrm{G}$ activation of $\mathrm{p} 21^{\text {ras }}$. Proc Natl Acad Sci USA 1994; 91: 12706-10.

4.- Gutkind JS. The pathways connecting G protein-coupled receptors to the nucleus through divergent mitogenactivated protein kinase cascades. J Biol Chem 1998; 273: 1839-42.

5.- Ji TH, Grossmann M, Ji I. G protein-coupled receptors. I. Diversity of receptor-ligand interactions. J Biol Chem 1998; 273: 17299-302.

6.- Lefkowitz RJ. G protein-coupled receptors. III. New roles for receptor kinases and -arrestines in receptor signaling and desensitization. J Biol Chem 1998; 73: 18677-80.

7.- Hepler JR, Gilman AG. G proteins. Trends Biochem Sci 1992; 17: 383-7.

8.- Gautam N, Downes GA, Yan K, Kisselev O. The G-protein complex. Cell Signal 1998; 10: 447-55.

9.- Gether U, Kobilka B. G protein-coupled receptors. II. Mechanism of agonist activation. J Biol Chem 1998; 273: 17979-82.

10.- Strange PG. G-protein coupled receptors. Conformations and states. Biochem Pharmacol 1999; 58: 1081-8.

11.- Alberts B, Bray D, Lewis J, Raff M, Roberts K, Watson JD. Molecular biology of the cell. 3a. ed. New York: Garland; 1994. pp. 721-785.

12.- Way KJ, Chou E, King GL. Identification of PKC-isoformspecific biological actions using pharmacological approaches. Trends Pharmacol Sci 2000; 21: 181-7.

13.- Soria LE, Arias-Montaño JA. (1997). Señalización por segundos mensajeros. En: Hiriart M, García E, García J, Velázquez SJ, editores. Actualización en Fisiología. Morelia, SMCF/UMSNH; 1997.pp. 85-104.

14.- Ullrich A, Schlessinger J. Signal transduction by receptors with tyrosine kinase activity. Cell 1990; 61: 203-12.

15.- Hurwitz DR, Emanuel SL, Nathan MH, Sarver N, Ullrich A, Felder S, Lax I, Schlessinger J. EGF induces incresed ligand binding affinity and dimerization of a soluble epidermal growth factor (EGF) receptor extracellular domain. J Biol Chem 1991; 266, 22035-43.

16.- Pazin MJ, Williams LT. Triggering signaling cascades by receptor tyrosine kinases. Trends Biochem Sci 1992; 17: 374-8.

17.- Matozaki T, Nakanishi H, Takai Y. Small G-protein networks. Their crosstalk and signal cascades. Cell Signal 2000; 12: 515-24.

18.- Pelech SL, Sanghera JS. Mitogen-activated protein kinases: versatile transducers for cell signalling. Trends Biochem Sci 1992; 17: 233-8.

19.- Treisman R. Regulation of transcription by MAP kinase cascades. Curr Opin Cell Biol 1996; 8: 205-15.

20.- Pellegrini S, Dusanter-Fourt I. The structure, regulation and function of the Janus kinases (JAKs) and the signal transducers and activators of transcription (STATs). Eur J Biochem 1997; 248: 615-33.

21.- Liu KD, Gaffen SL, Goldsmith MA. JAK/STAT signaling by cytokine receptors. Curr Opin Immunol 1998; 10: 271-8.

\section{Revista Biomédica}




\section{Receptores de cinasa de tirosina y receptores acoplados a proteínas $G$.}

22.- Carter-Su C, Smit LS. Signaling via JAK tyrosine kinases: growth hormone receptor as a model system. Recent Prog Horm Res 1998; 53: 61-82.

23.- Cazaubon SM, Ramos-Morales F, Fischer S, Schweighoffer F, Strosberg AD, Couraud PO. Endothelin induces tyrosine phosphorylation and Grb2 association of Shc in astrocytes. J Biol Chem 1994; 269: 24805-9.

24.- Chen Y, Grall D, Salcini AE, Pelicci PG, Pousségur J, van Obberghen-Schilling E. Shc adaptor proteins are key transducers of mitogenic signaling mediated by the $\mathrm{G}$ proteincoupled thrombin receptor. EMBO J 1996; 15: 1037-44.

25.- Sadoshima J, Izumo S. The heterotrimeric Gq proteincoupled angiotensin II receptors activates $\mathrm{p} 21^{\text {ras }}$ via the tyrosine kinase-Shc-Grb2-Sos pathway in cardiac myocytes. EMBO J 1996; 15: 775-87.

26.- Rosen LB, Greenberg ME. Stimulation of growth factor receptor signal transduction by activation of voltajesensitive calcium channels. Proc Natl Acad Sci USA 1996; 93: 1113-8.

27.- Sachsenmaier C, Radler-Pohl A, Zinck R, Nordheim A, Herrlich P, Rohmsdorf J. Involvement of groth factor receptors in the mammalian UVC response. Cell 1994; 78: 963-72.

28.- Coffer PJ, Burgering BM, Peppelenbosch MP, Bos JL, Kruijer W. UV activation of receptor tyrosine kinase activity. Oncogene 1995; 11: 561-9.

29.- Knebel A, Rahmsdorf HJ, Ullrich A, Herrlich P. Dephosphorylation of receptor tyrosine kinases as target of regulation by radiation, oxidants or alkylating agents. EMBO J 1996; 15: 5314-25.

30.- Daub H, Wallasch C, Lankenau A, Herrlich A, Ullrich A. Signal characteristics of $\mathrm{G}$ protein-transactivated EGF receptor. EMBO J 1997; 6: 7032-44.

31.- Linseman DA, Benjamin CW, Jones DA. Convergence of angiotensin II and platelet-derived growth factor receptor signaling cascades in vascular smooth muscle cells. J Biol Chem 1995; 270: 12563-8.

32.- Rao GN, Delafontaine P, Runge MS. Thrombin stimulates phosphorylation of insulin-like growth factor-1 receptor, insulin receptor substrate-1, and phospholipase $\mathrm{C} 1$ in rat aortic smooth muscle cells. J Biol Chem 1995; 270: 27871-5.

33.- Weiss FU, Daub H, Ullrich A. Novel mechanism of RTK signal generation. Curr Opin Genet Dev 1997; 7: 80-6.

34.- Prenzel N, Zwick E, Daub H, Leserer M, Abraham R, Wallasch C, Ullrich A. EGF receptor transactivation by Gprotein-coupled receptors requires metalloproteinase cleavage of proHB-EGF. Nature 1999; 402: 884-8.

35.- Keely SJ, Uribe JM, Barrett KE. Carbachol stimulates transactivation of epidermal growth factor and mitogenactivated protein kinase in T84 cells. J Biol Chem 1998; 273: 27111-7.

36.- Daub H, Ulrich-Weiss F, Wallasch C, Ullrich A. Role of transactivation of the EGF receptor in signalling by Gprotein-coupled receptors. Nature 1996; 379: 557-60.

37.- Herrich A, Daub H, Knebel A, Herrlich P, Ullrich A, Schultz G, Gudermann T. Ligand-independent activation of platelet-derived growth factor receptor is a necessary intermediate in lysophosphatidic acid-stimulated mitogenic activity in L cells. Proc Natl Acad Sci USA 1998; 95: 8985-90.

38.- Crespo P, Xu N, Daniotti JL, Troppmair J, Rapp UR, Gutkind JS. Signaling through transforming G proteincoupled receptors in NIH $3 \mathrm{~T} 3$ cells involves c-Raf activation. Evidence for a protein kinase C-independent pathway. J Biol Chem 1994; 269: 21103-9.

39.- Ptasznik A, Traynor-Kaplan A, Bokoch GM. G proteincoupled chemoattractant receptors regulate Lyn tyrosine kinase-Shc adapter protein signaling complexes. J Biol Chem 1995; 270: 19969-73.

40.- Daaka Y, Luttrell LM, Lefkowitz RJ. Switching of the coupling of the beta2-adrenergic receptor to different $\mathrm{G}$ proteins by protein kinase A. Nature 1997; 390: 88-91.

41.- Maudsley S, Pierce KL, Zamah AM, Miller WE, Ahn S, Daaka Y, Lefkowitz RJ, Luttrell LM. The ${ }_{2}$-adrenergic receptor mediates extracellular signal-regulated kinase activation via assembly of a multi-receptor complex with the epidermal growth factor receptor. J Biol Chem 2000; 275: 9572-80.

42.- Luo X, Zeng W, Popov S, Davignon I, Wilkie TM, Mumby SM, Muallem,S. Alternate coupling of receptors to Gs and $\mathrm{Gi}$ in pancreatic and submandibular gland cells. J Biol Chem 1999; 274: 17684-90.

43.- Hawes BE, van Biesen T, Koch WJ, Luttrell LM, Lefkowitz RJ. Distinct pathways of Gi- and Gq -mediated mitogenactivated protein kinase activation. J Biol Chem 1995; 270: 17148-53. 


\section{E Sánchez-Lemus, JA Arias-Montaño.}

44.- Della-Rocca, van Biesen T, Daaka Y, Luttrell LM, Lefkowitz RJ. Ras-dependent motigen-activated protein kinase activation by $\mathrm{G}$ protein-coupled receptors. Convergence of Gi- and Gq-mediated pathways on calcium/ calmodulina, Pyk2, and Src kinase. J Biol Chem 1997; 272: 31648-56.

45.- Tsai W, Morielli AD, Peralta EG. The m1 muscarinic acetylcholine receptor transactivates the EGF receptor to modulate ion channel activity. EMBO J 1997; 16: 4597-4605.

46.- Crespo P, Xu N, Simonds WF, Gutkind JS. Ras-dependent activation of MAP kinase pathway mediated by G-protein subunits. Nature 1994; 369: 418-20.

47.- Luttrell LM, Della-Rocca GJ, van Biesen T, Luttrell DK, Lefkowitz RJ. G betagamma subunits mediate Src-dependent phosphorylation of the epidermal growth factor receptor. A scaffold for $\mathrm{G}$ protein-coupled receptor-mediated Ras activation. J Biol Chem 1997; 272: 4637-44.

48.- Pierce KL, Tohgo A, Ahn S, Field ME, Luttrell LM, Lefkowitz RJ. Epidermal growth factor (EGF) receptordependent ERK activation by $\mathrm{G}$ protein-coupled receptors. J Biol Chem 2001; 276: 23155-60.

49.- Neelam B, Richter A, Chamberlin SG, Puddicombe SM, Wood L, Murray MB, Nandagopal K, Niyogi SK, Davies DE. Structure-function studies of ligand-induced epidermal growth factor receptor dimerization. Biochem 1998; 37: 488491.

50.- Porter TE, Wiles CD, Frawley LS. Lactotrope differentiation in rats is modulated by a milk-born signal transferred to the neonatal circulation. Endocrinology 1993; 133: 1284-91.

51.- Murali R, Brennan PJ, Kieber-Emmons T, Breene MI. Structural análisis of $\mathrm{p} 185^{\mathrm{c}-\mathrm{neu}}$ and epidermal growth factor receptor tyrosine kinases: oligomerizations of kinase domains. Proc Natl Acad Sci USA 1996; 93: 6252-7.

52.- Downward J. The GRB2/sem-5 adaptor protein. FEBS Lett 1994; 338: 113-7.

53.- Holgado-Madruga M, Emlet DR, Moscatello DK, Godwin AK, Wong AJ. A Grb2-associated docking protein in EGFand insulin-receptor signalling. Nature 1999; 379: 560-4.

54.- Vieira AV, Lamaze C, Schmid SL. Control of EGF receptor signaling by clathrin-mediated endocytosis. Science 1996; 274: 2086-9.

\section{Revista Biomédica}

55.- Chow JC, Condorelli G, Smith RJ. Insulin-like growth factor-1 receptor internalization regulates signaling via the Shc/mitogen-activated protein kinase pathway, but not the insulin receptor substrate-1 pathway. J Biol Chem 1998; 273 : 4672-80.

56.- Vogler O, Nolte B, Voss M, Schimdt M, Jakobs KH, van Koppen CJ. Regulation of muscarinic acetylcholine receptor sequestration and function by beta-arrestin. J Biol Chem 1999; 274: 12333-8.

57.- Ignatova EG, Belcheva MM, Bohn LM, Neuman MC, Coscia CJ. Requirement of receptor internalization for opioid stimulation of mitogen-activated protein kinase: biochemical and immunofluorescence confocal microscopic evidence. J Neurosci 1999; 19: 56-63.

58.- Ahn S, Maudsley S, Luttrell LM, Lefkowitz RJ, Daaka Y. Src-mediated tyrosine phosphorylation of dynamin is required for beta2-adrenergic receptor internalization and mitogen-activated protein kinase signaling. J Biol Chem 1998; 274: $1185-8$.

59.- Wilde A, Beattie EC, Lem L, Riethof DA, Liu SH, Mobley WC, Soriano P, Brodsky FM. EGF receptor signaling stimulates SRC kinase phosphorylation of clathrin, influencing clathrin redistribution and EGF uptake. Cell 1999; $96,677-87$.

60.- Selbie LA, Hill SJ. G protein-coupled-receptor crosstalk: the fine-tuning of multiple receptor-signalling pathways. Trends Pharmacol Sci 1998; 19: 87-93.

61.- Hill SM. Receptor crosstalk: communication through cell signaling pathways. Anat Rec 1998; 253: $42-8$.

62.- Cordeaux Y, Hill SJ. Mechanisms of cross-talk between G-protein-coupled receptors. Neurosignals 2002; 11: 45-57.

63.- Hur EM, Kim KT. G protein-coupled receptor signaling and cross-tal. Achieving rapidity and specificity. Cell Signal 2002; 14: 397-405.

64.- Morris AJ, Malbon CC. Physiological regulation of G protein-linked signaling. Physiol Rev 1999; 79: 1373-430.

65.- Marinissen MJ, Gutkind JS. G-protein-coupled receptors and signaling networks: emerging paradigms. Trends Pharmacol Sci 2001; 22: 368-76.

66.- Hong WK, Ullrich A. The role of EGFR in solid tumors and implications for therapy. Oncology biotherapeutics. Vol.1, No.1. Darmstadt: Gardiner-Caldwell, 2000. pp. 1-29. 